\title{
Komputasi Paralel Menggunakan Model Message Passing Pada SIM RS (Sistem Informasi Manajemen Rumah Sakit)
}

\author{
I Putu Adi Pradnyana Wibawa ${ }^{1}$, I.A. Dwi Giriantari ${ }^{2}$, Made Sudarma ${ }^{3}$
}

\begin{abstract}
The development of increasingly rapid the data can go beyond the capabilities of the device database management. One example of a system that has a high data complexity is the SIM RS (hospital management information system). In this study a patient's data on a SIM RS to be used as an object model using Parallel implementations of message-passing. Parallel computing is designed in a way to divide the execution data to a number of computer/CPU. The testing will be done by comparing the data processing time between sequential and parallel. In addition, parallel will be tested using the calculation Speed Up and Efficiency. The test results proved that the data processing time patients using parallel programs faster than using sequential topology. On speed up testing showed an increased speed until the use of 3 computers/CPU. While in testing the efficiency of the highest efficiency values contained on the use of 2 and 3 computers/CPU. The decline in the value of the speed up and efficiency due to the amount of data that belongs to a little when handled by 7 computers/CPU. So the greater number of computer/CPU is involved, it is not directly proportional to the time taken in processing/data processing. This is due to a job processing/data processing in terms of the amount of data handled has a limited number of ideal computer/CPU to handle the job.
\end{abstract}

Intisari- Perkembangan data yang semakin pesat dapat melampaui batas kemampuan perangkat manajemen database. Salah satu contoh sistem yang memiliki kompleksitas data yang tinggi adalah SIM RS (Sistem Informasi Manajemen Rumah Sakit). Dalam penelitian ini data pasien pada SIM RS akan digunakan sebagai objek implementasi Komputasi Paralel menggunakan model message-passing. Komputasi paralel didesain dengan cara membagi eksekusi data ke sejumlah komputer/CPU. Pengujian akan dilakukan dengan membandingkan waktu pengolahan data antara sekuensial dan paralel. Selain itu komputasi paralel akan diuji menggunakan perhitungan Speed $U p$ dan Efisieinsi. Hasil pengujian membuktikan bahwa waktu pengolahan data pasien menggunakan program paralel lebih cepat dibandingkan menggunakan topologi sekuensial. Pada pengujian speed up menunjukan peningkatan kecepatan sampai pada penggunaan 3 komputer/CPU. Sedangkan pada pengujian efisiensi nilai efisiensi tertinggi terdapat pada penggunaan 2 dan 3 komputer/CPU. Penurunan nilai speed up dan efisiensi diakibatkan oleh jumlah data yang tergolong sedikit apabila ditangani oleh 7 komputer/CPU. Jadi semakin banyak jumlah komputer/CPU yang dilibatkan, tidak berbanding lurus dengan waktu yang dibutuhkan dalam pemrosesan/ pengolahan data tersebut. Hal ini dikarenakan sebuah pekerjaan

\footnotetext{
${ }^{1}$ Mahasiswa, Program Studi Magister Teknik Elektro, Jalan Dewi Supraba VI. No.23 ,Denpasar Bali INDONESIA (tlp:081916153335; e-mail: adipwgirondins@gmail.com)

2, 3 Dosen, Program Studi Magister Teknik Elektro, Jalan Panglima Besar Sudirman, Denpasar Bali Indonesia (tlp: 0361239599; fax: 0361-239599; e-mail: dayu.giriantari@unud.ac.id, imasudarma@gmail.com)
}

pemrosesan/pengolahan data dalam hal jumlah data yang ditangani memiliki batas ideal jumlah komputer/CPU yang menangani pekerjaan tersebut.

Kata Kunci- Komputasi Paralel, Message-passing, Metode Foster, SIM RS

\section{Pendahuluan}

Perkembangan teknologi informasi meliputi perkembangan infrastruktur pendukungnya, yaitu hardware, software, teknologi komunikasi dan teknologi penyimpanan data. Semakin berkembangnya teknologi akan berdampak pada pertumbuhan data yang berlipat ganda dari waktu ke waktu. Data menjadi semakin luas dan kompleks hingga melampaui batas kemampuan aplikasi pemroses ataupun database manajemen tools yang ada, dilatarbelakangi hal tersebut munculah istilah Big Data. Kemunculan big data seolah menjadi permasalahan yang cukup kompleks dihadapi oleh organisasi pengguna sistem dengan tingkat pertumbuhan data yang cepat dan pengolahan data yang besar.

Salah satu sistem yang memiliki jumlah dan jenis data yang cukup besar adalah SIM RS. Berdasarkan ketentuan Pasal 52 ayat (1) Undang- Undang Nomor 44 Tahun 2009 tentang Rumah Sakit, setiap rumah sakit wajib melakukan pencatatan dan pelaporan semua kegiatan penyelenggaraan rumah sakit dalam bentuk SIM RS. Pemanfaatan SIM RS yang telah berjalan optimal akan menjadikan jumlah data semakin besar terutama data dengan jenis teks berupa angka (nomor rekam medis pasien), dan huruf (biodata pasien). Untuk memunculkan output dari data-data tersebut dibutuhkan proses komputasi dan pengolahan data dalam jumlah besar, yang sudah barang tentu kinerja server akan sangat berat sehingga tidak menutup kemungkinan terjadinya hang akibat kelebihan beban. HPC (High Performance Computing) merupakan metode untuk mengatasi permasalahan yang memiliki kompleksitas tinggi terkait dengan beban pekerjaan dan penggunaan banyak data [9]. Salah satu teknik yang digunakan dalam metode HPC adalah Komputasi Paralel. Komputasi parallel adalah salah satu teknik melakukan komputasi secara bersamaan dengan memanfaatkan beberapa komputer independen secara bersamaan.

Pemanfaatan komputasi paralel banyak digunakan dalam berbagai pemecahan masalah pada berbagai bidang ilmu. Pada [10] melakukan penelitian mengenai pengolahan gambar digital menggunakan komputasi paralel. Pendekatan yang digunakan adalah menggunkan CUDA sebagai alat pemrograman paralel pada GPU untuk mengambil resources dari semua core yang tersedia. Pada [18] melakukan proses enkripsi citra menggunakan algoritma Advanced Encryption Standard (AES). Untuk mempercepat waktu enkripsi diterapkan komputasi paralel. Perangkat komputasi paralel 
yang digunakan adalah Java Parallel Programming Framework (JPPF) yang berarsitektur master/slave. Selain membahas mengenai pemanfaatan komputasi paralel, terdapat pula penelitian yang mengkaji perbandingan perangkatbantu permrograman paralel. Pada [5] dilakukan perbandingan serta analisis kemampuan komputasi paralel antara perangkatbantu OpenMP dan MPI (Message Passing Interface). Berdasarkan penelitian yang dilakukan tersebut, disimpulkan bahwa komputasi paralel menggunakan MPI memiliki kemampuan yang baik saat digunakan dalam metode paralel terhadap sistem dengan kompleksitas data yang besar.

Dalam Penelitian ini pemanfaatan komputasi paralel menggunakan MPI diharapkan mampu meningkatkan kemampuan komputasi sehingga mampu menjadi alternatif solusi bagi permasalahan beban data dan kecepatan waktu komputasi yang terjadi pada SIM RS. Hal ini memberikan motivasi dalam perancangan komputasi paralel dengan melakukan pembagian eksekusi data kepada beberapa komputer/CPU yang saling tehubung. Proses komputasi paralel bagi data dilakukan karena jumlah data pada SIM RS cukup besar dan antara satu data dengan data yang lainnya tidak saling berkaitan. Dengan menggunakan model messagepassing pada library MPI pengolahan data difokuskan pada proses pencarian data manajemen rumah sakit. Sebuah komputer/CPU akan difungsikan sebagai master dimana proses komputasi akan dibantu oleh beberapa komputer/CPU yang akan berfungsi sebagai slave. Pembagian dan eksekusi data (paralel bagi data) kepada masing-masing komputer/CPU slave akan dilakukan oleh komputer/CPU master. Dengan demikian sumber daya komputer yang tersedia dapat dimanfaatkan semaksimal mungkin untuk membantu kinerja komputer/CPU master. Speedup dan efisiensi digunakan untuk mengukur seberapa baik arsitektur paralel yang diterapkan.

\section{Metode Penelitian}

Komputasi Paralel merupakan metode komputasi yang membagi beban komputasi ke dalam beberapa bagian kecil sub proses komputasi, dimana sub komputasi tersebut dijalankan pada processor yang berbeda secara bersamaan dan saling berinteraksi satu sama lain dalam menyelesaikan satu permasalahan komputasi. Salah satu protokol dalam pemrograman parallel adalah MPI yang dikembangkan dalam skema distributed memory [12]. MPI mengijinkan pertukaran data (message) antara processor. Dalam penelitian ini komputasi paralel difokuskan pada pengolahan/pencarian data pasien pada data base SIM RS. Komputasi paralel didesain untuk mengurangi waktu komputasi saat melakukan proses pengolahan data manajemen rumah sakit pada SIM RS.

Pada Gambar 1. digambarkan bahwa proses pengolahan data yang sebelumnya dilakukan secara sekuensial (satu data dalam satu waktu dan satu komputer/CPU) akan dikerjakan secara bersamaan dengan beberapa komputer/CPU. Dalam proses kerja Komputasi Paralel menggunakan MPI membutuhkan Komputer/CPU yang memiliki peranan berbeda yaitu sebagai master dan slave. Komputer/CPU yang berfungsi sebagai master akan menginstruksikan komputer/CPU slave untuk mengolah data dan mengirim kembali output yang telah diperoleh ke komputer/CPU master sebagai hasil dari pengolahan data menggunakan komputasi paralel. Dalam perancangan penelitian terdapat beberapa tahapan yang digunakan yaitu sebagai berikut:

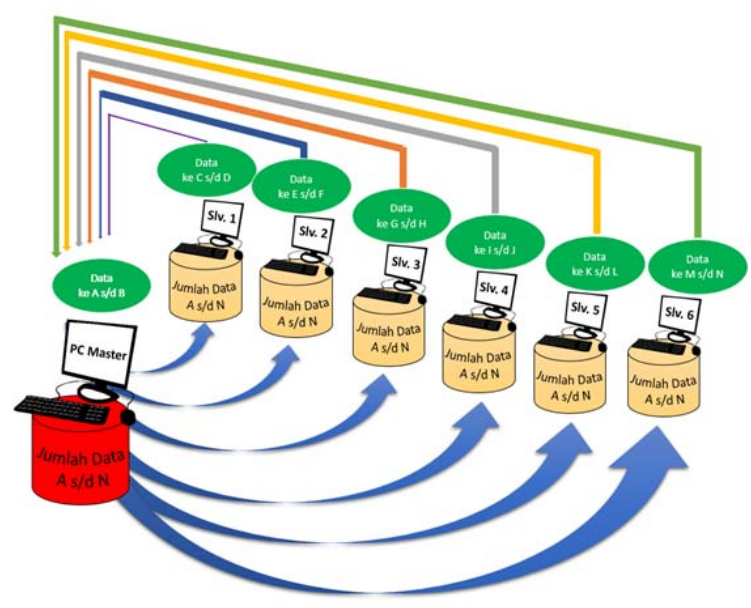

Gambar 1: Topologi Pembagian Beban Kerja Komputasi Paralel SIM RS

\section{A. Pengumpulan Data dan Analisis Kebutuhan}

Teknik pengumpulan data yang digunakan adalah observasi, dan studi literatur. Observasi ini dimaksudkan untuk mengamati SIM RS yang telah berjalan dan proses pengolahan data dalam memenuhi kebutuhan manajemen rumah sakit. Sedangkan teknik Studi Literatur yaitu mencari referensi teori yang relevan dengan penelitian yang dilakukan.

Dalam tahap ini dilakukan pengumpulan data berupa Proses/alur kerja SIM RS yang telah berjalan dan Pengambilan data pasien yang ada pada data base SIM RS. Sesuai dengan hasil analisis kebutuhan yang dilakukan bersama pihak administrator SIMRS, tabel kunjungan_id dengan jumlah data sebanyak 40.036 digunakan sebagai tabel objek pengolahan data menggunakan program MPI. Tabel kunjungan_id merupakan Primary Key pada database his_db SIM RS, dimana semua tabel yang terdapat pada data base his_db mengambil data dan mengirimkan data pada tabel tersebut. Data pada tabel kunjungan_id akan dibagi menjadi beban kerja ke masing-masing komputer/CPU slave sesuai jumlah komputer/CPU slave yang ditentukan dalam mengeksekusi query pengolahan data.

\section{B. Perancangan dan Konfigurasi Local Area Network (LAN)}

Berdasarkan konsep arsitektur jaringan komputasi parallel yang menggunakan lebih dari 1 komputer/CPU dan ketersediaan perangkat komputer/CPU sesuai ijin dari pihak rumah sakit, maka pada penelitian ini topologi $L A N$ memanfaatkan 7 unit komputer/CPU dimana 1 unit komputer/CPU difungsikan sebagai master dan 6 unit komputer/CPU difungsikan sebagai slave. Sedangkan untuk dapat membandingkan kinerja komputasi dengan arsitektur parallel dan sekuensial, maka diperlukan perancangan arsitektur sekuanseial dengan menggunakan 1 unit komputer/CPU difungsikan sebagai master dan 1 unit 
komputer/CPU difungsikan sebagai slave. Untuk kedua arsitektur tersebut dapat digambarkan pada Gambar 2 dan Gambar 3.

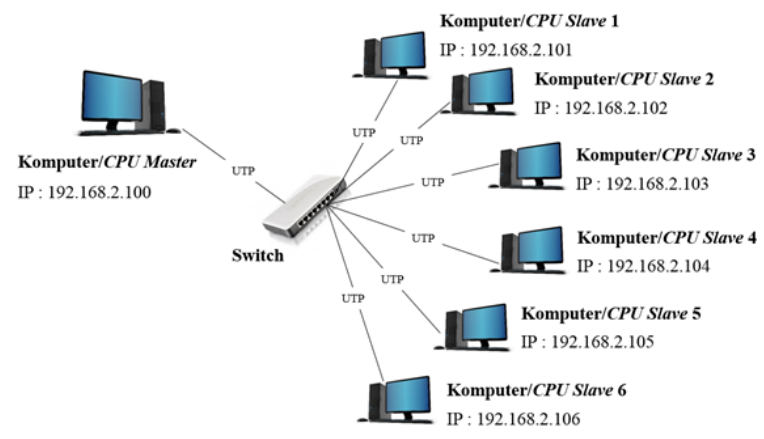

Gambar 2: Arsitektur Parallel

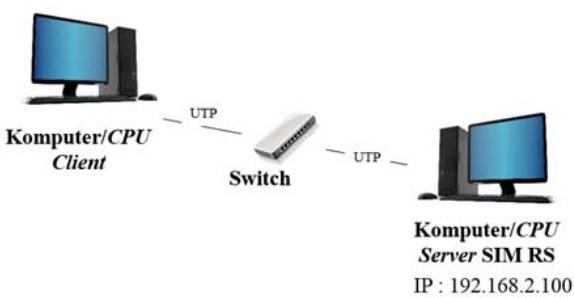

Gambar 3: Arsitektur Sekuensial

\section{Installasi Software}

Software yang dibutuhkan dalam penelitian ini adalah :

1. XAMPP (MYSQL) sebagai data base data pasien pada SIM RS.

2. SQLyog, tools yang digunakan untuk melakukan eksekusi query.

3. Bahasa pemrograman C. Untuk memfasilitasi proses perancangan coding komputasi paralel menggunakan bahasa pemrograman $\mathrm{C}$ dibutuhkan installasi software Microsoft Visual Studio .

4. Library MPI. Dalam penggunaan model message-passing dalam perancangan komputasi paralel dibutuhkan library MPI yang berjalan sesuai dengan sistem operasi yang digunakan. Pada penelitian ini sistem operasi yang digunakan adalah Windows, untuk library MPI menggunakan MPICH2 .

\section{Konfigurasi Komputasi Paralel}

Konfigurasi komputasi paralel pada komputer/CPU master dan slave menggunakan metode Foster dengan langkah sebagai berikut :

1. Langkah pertama metode Foster untuk mendesain komputasi paralel adalah proses partisi. Pembagian dilakukan dengan membagi dan menyebarkan data pasien ke sejumlah $p$. Sehingga dalam kondisi ideal, komputer/CPU akan mengolah sebanyak $N / p$ data, dengan $N$ merupakan jumlah data dan $p$ merupakan jumlah komputer/CPU.

2. Langkah kedua adalah menentukan komunikasi dalam desain paralel. Komunikasi terjadi pada saat proses pembagian data dari komputer/CPU master ke sejumlah komputer/CPU slave. Komunikasi yang terjadi adalah collective communication. Collective communication merupakan komunikasi yang terjadi antara komputer/CPU master dengan semua komputer/CPU slave yang ada

3. Langkah ketiga adalah proses mengelompokkan task ke dalam task yang lebih besar guna meningkatkan kinerja maupun menyederhanakan pemrograman atau yang disebut dengan proses aglomerasi

4. Langkah terakhir adalah memaksimalkan kemampuan komputer/CPU dan meminimalkan komunikasi antar komputer/CPU atau yang disebut proses pemetaan. Kemampuan komputer/CPU adalah persentasi rata-rata waktu komputer/CPU dalam mengeksekusi suatu task untuk menyelesaikan suatu masalah dan memberi suatu solusi penyelesaian.

\section{E. Input Perintah}

Tahap ini dilakukan untuk mengetahui jumlah data dari eksekusi query menggunakan tools SQLyog. Dalam penelitian ini digunakan query yang membutuhkan waktu eksekusi cukup kompleks yaitu query dalam mencari data Laporan Tampil Kunjungan Pasien berdasarkan Jenis Bayar (JKBM) dan Nama Tindakan Per Poliklinik (MATA) dalam periode waktu dari tanggal 1 bulan Januari tahun 2014 sampai dengan tanggal 1 bulan Januari tahun 2015. Dari hasil eksekusi query tersebut pada database his_db akan didapat data records sebanyak 9.493 .

\section{F. Pengujian Sistem}

Pengujian terhadap penelitian ini difokuskan pada dua aspek yaitu speedup dan efisiensi. Proses pengujian dengan menguji Speedup adalah nilai yang diperoleh dari perbandingan antara waktu proses komputasi serial dengan waktu proses komputasi paralel. Pengujian efisiensi pada pengujian ini adalah perbandingan antara nilai speed up yang dihasilkan dari banyaknya komputer/CPU yang digunakan untuk mencapai nilai tersebut.

\section{HASIL DAN PEMBAHASAN}

\section{A. Program MPI Pada Topologi Jaringan Sekuensal dan Topologi Paralel}

Tahap berikutnya adalah dengan menguji apakah program paralel telah berjalan sesuai konsep penelitian yang telah direncanakan yaitu dengan mengolah data SIM RS menggunakan topologi jaringan sekuensial (1 komputer/CPU) dan mengolah data SIMRS menggunakan program paralel MPI dengan topologi jaringan paralel yaitu menggunakan 1 komputer/CPU berfungsi sebagai master dan 6 komputer/CPU sebagai slave dengan total 7 komputer/CPU baik master ataupun slave dapat berfungsi mengolah data. 


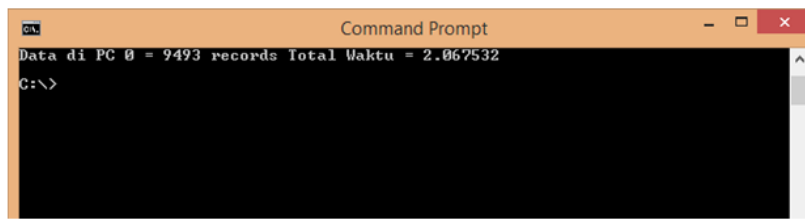

Gambar 4: Hasil Program MPI Pada Topologi Jaringan Sekuensial (1 Komputer/CPU)

Pada Gambar 4 menunjukan hasil pengolahan data pada topologi jaringan sekuensial (1 komputer/CPU) dengan nama host MPI100. Dari total 40.036 records data yang ada pada tabel kunjungan_id eksekusi query dalam mencari data Laporan Tampil Kunjungan Pasien berdasarkan Jenis Bayar (JKBM) dan Nama Tindakan Per Poliklinik (MATA) periode waktu dari tanggal 1 bulan Januari tahun 2014 sampai dengan tanggal 1 bulan Januari tahun 2015 menggunakan program MPI menghasilkan 9.493 records data. Jumlah records data ini sesuai dengan jumlah data yang didapat pada uji eksekusi query pada tahap input perintah sebelumnya, hal ini membuktikan bahwa program MPI berjalan sesuai hasil yang diinginkan. Waktu yang dibutuhkan dalam proses eksekusi adalah 2,067532 detik. Pada tahap selanjutnya akan dilakukan pengujian menggunakan program paralel MPI pada topologi jaringan paralel menggunakan masing-masing 2,3,4,5,6, dan 7 komputer/CPU untuk kemudian waktu pengolahan data masing-masing akan dibandingkan dengan waktu pengolahan data pada topologi jaringan sekuensial/1 komputer/CPU.

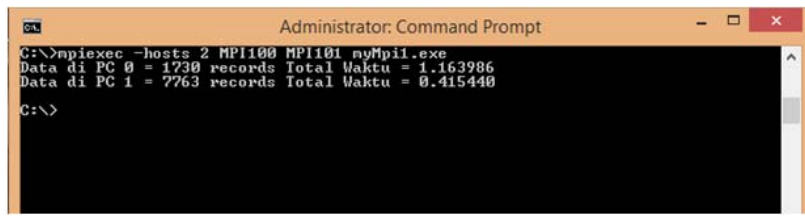

Gambar 5: Hasil program MPI pada topologi jaringan paralel menggunakan 2 komputer/CPU

Gambar 5 menunjukan pengujian program paralel MPI pada topologi jaringan paralel menggunakan 2 komputer/CPU , masing-masing komputer/CPU menghasilkan records data sebanyak 1.730 dan 7.763 dengan total jumlah records data sebanyak 9.493. Hasil pengujian tersebut jika dibandingkan dengan pengujian pada topologi jaringan sekuensial (1 komputer/CPU), terdapat peningkatan kecepatan pengolahan data selama 0,903546 detik.

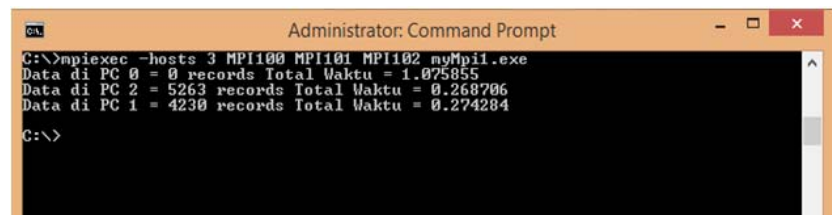

Gambar 6: Hasil program MPI pada topologi jaringan paralel menggunakan 3 komputer/CPU

Gambar 6 menunjukan pengujian program paralel MPI pada topologi jaringan paralel menggunakan 3 komputer/CPU (host MPI100, MPI101 dan MPI102) total waktu yang dibutuhkan dalam proses pengolahan data yaitu selama 1,075855 detik. Dari hasil pengujian tersebut jika dibandingkan dengan pengujian pada topologi jaringan paralel 2 komputer/CPU, terdapat peningkatan kecepatan pengolahan data selama 0,088131 detik.

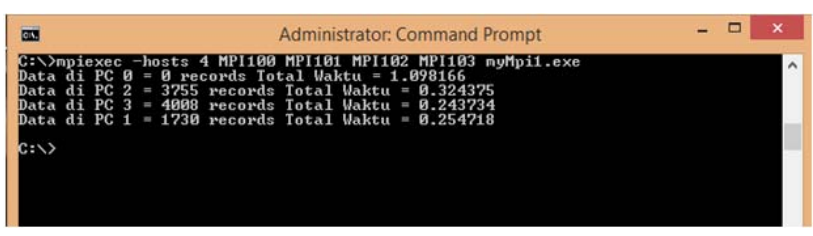

Gambar 7: Hasil program MPI pada topologi jaringan paralel menggunakan 4 komputer/CPU

Gambar 7 menunjukan pengujian program paralel MPI pada topologi jaringan paralel menggunakan 4 komputer/CPU (host MPI100, MPI101, MPI102 dan MPI103) waktu yang dibutuhkan adalah 1,098166 detik.. Dari hasil pengujian tersebut jika dibandingkan dengan pengujian pada topologi jaringan paralel 3 komputer/CPU, terdapat penurunan kecepatan pengolahan data selama 0,022311 detik.

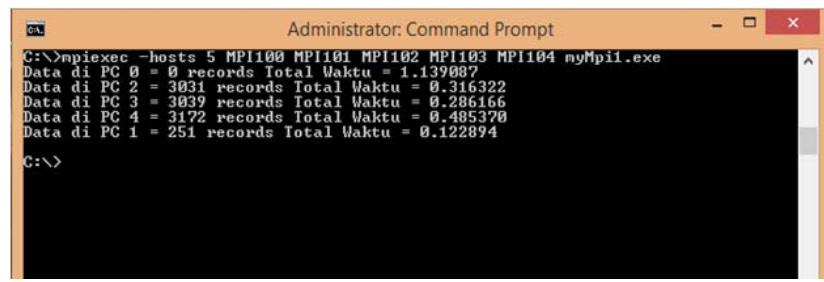

Gambar 8: Hasil program MPI pada topologi jaringan paralel menggunakan 5 komputer/CPU

Gambar 8 menunjukan pengujian program paralel MPI pada topologi jaringan paralel menggunakan 5 komputer/CPU (host MPI100, MPI101, MPI102, MPI103 dan MPI104) waktu yang dibutuhkan adalah 1,139087 detik. Dari hasil pengujian tersebut jika dibandingkan dengan pengujian pada topologi jaringan paralel 4 komputer/CPU, terdapat penurunan kecepatan pengolahan data selama 0,040921 detik

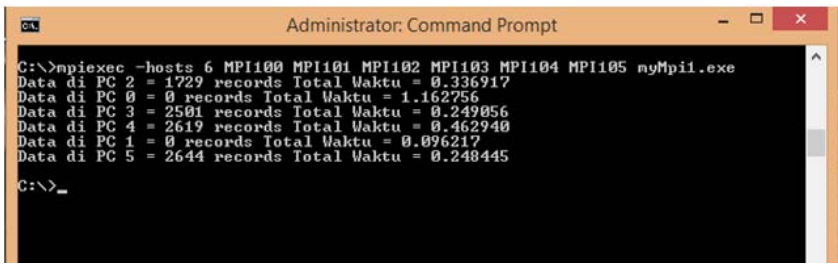

Gambar 9: Hasil program MPI pada topologi jaringan paralel menggunakan 6 komputer/CPU

Gambar 9 menunjukan pengujian program paralel MPI pada topologi jaringan paralel menggunakan 6 komputer/CPU (host MPI100, MPI101, MPI102, MPI103, MPI104 dan MPI105) waktu yang dibutuhkan adalah 1,162756 detik. Dari hasil pengujian tersebut jika dibandingkan dengan pengujian pada topologi jaringan paralel 5 komputer/CPU, terdapat penurunan kecepatan pengolahan data selama 0,023669 detik. 


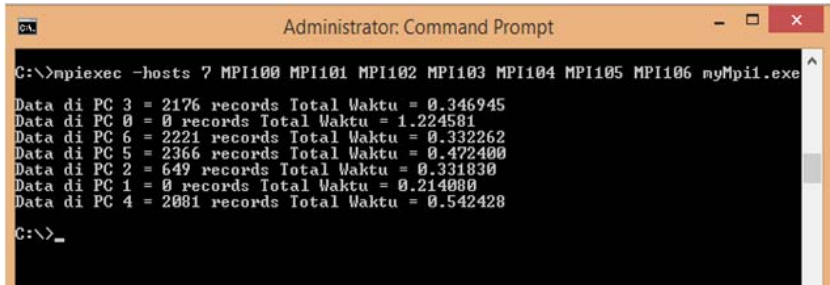

Gambar 10: Hasil program MPI pada topologi jaringan paralel menggunakan 7 komputer/CPU

Gambar 10 menunjukan pengujian program paralel MPI pada topologi jaringan paralel menggunakan 7 komputer/CPU (host MPI100, MPI101, MPI102, MPI103, MPI104, MPI105 dan MPI106 waktu yang dibutuhkan adalah 1,224581 detik. Dari hasil pengujian tersebut jika dibandingkan dengan pengujian pada topologi jaringan paralel 6 komputer/CPU, terdapat penurunan kecepatan pengolahan data selama 0,061825 detik.

\section{B. Pengujian Speed Up}

Speed up $(S)$ merupakan hasil perbandingan antara waktu sekuensial dengan waktu paralel. Pada hasil pengujian tahap sebelumnya hasil pengolahan data pada topologi jaringan sekuensial/1 komputer/CPU membutuhkan waktu 2,067532 detik. Untuk mengetahui nilai speed up maka waktu hasil pengolahan data topologi jaringan sekuensial (1 komputer/CPU) akan dibagi waktu pengolahan data menggunakan program paralel MPI sesuai dengan jumlah komputer/CPU yang digunakan.

TABEL I

HASIL PENGUJIAN SPEED UP

\begin{tabular}{|c|c|c|c|}
\hline $\begin{array}{c}\text { Jumlah } \\
\text { komputer/C } \\
P U(p)\end{array}$ & $\begin{array}{c}\text { Waktu paralel } \\
(T p) \\
(\text { detik})\end{array}$ & $\begin{array}{c}\text { Speed } U p \\
(S)\end{array}$ & $\begin{array}{c}\text { Efisiensi } \\
(E)\end{array}$ \\
\hline 2 & 1,163986 & 1,78 & 0,89 \\
\hline 3 & 1,075855 & 1,92 & 0,64 \\
\hline 4 & 1,098166 & 1,88 & 0,47 \\
\hline 5 & 1,139087 & 1,81 & 0,36 \\
\hline 6 & 1,162756 & 1,78 & 0,30 \\
\hline 7 & 1,224581 & 1,69 & 0,24 \\
\hline
\end{tabular}

Hasil yang didapat dari pengujian speed up pada Tabel I menunjukan adanya peningkatan kecepatan sampai pada penggunaan komputasi paralel pada 3 komputer/CPU. Pengujian menggunakan 2 komputer/CPU memerlukan waktu selama 1,163986 detik dengan speed up mencapai 1,78 kali lebih cepat dari waktu sekuensial/1 komputer/CPU. Pengujian menggunakan 3 komputer/CPU memerlukan waktu selama 1,075855 detik dengan speed up mencapai 1,92 kali lebih cepat dari waktu sekuensial/1 komputer/CPU. Sedangkan pada pengujian menggunakan 4,5,6 dan 7 komputer/CPU speed up sudah mulai menurun seperti ditunjukan pada Gambar 11.
Penurunan kecepatan tersebut sangat mungkin terjadi berdasarkan Hukum Amdahl yang tercantum dalam buku Kurniawan, A (2010) mengenai Pemrograman Paralel MPI \& C, bahwa semakin banyak prosesor maka kecepatan akan sampai pada titik jenuh. Secara keseluruhan pengujian speedup pada penelitian ini jika dibandingkan dengan hasil pengolahan data menggunakan topologi jaringan sekuensial/1 komputer/CPU, pengolahan data menggunakan topologi jaringan paralel menggunakan 7 komputer/CPU terbukti memiliki kecepatan yang lebih baik.

\section{Pengujian Efisiensi}

Efisiensi $(E)$ merupakan perbandingan antara speed up $(S)$ dengan jumlah komputer/CPU yang digunakan $(p)$. Efisiensi mengukur seberapa efisien penggunaan sejumlah komputer/CPU di dalam topologi jaringan paralel yang dibangun. Penelitian ini mengukur nilai efisiensi pada topologi jaringan paralel menggunakan 7 komputer/CPU seperti pada Tabel II berikut.

TABEL II

HASIL PENGUJIAN EFISIENSI

\begin{tabular}{|c|c|c|}
\hline $\begin{array}{c}\text { Jumlah } \\
\text { komputer/CPU } \\
(p)\end{array}$ & $\begin{array}{c}\text { Waktu paralel (Tp) } \\
\text { (detik) }\end{array}$ & Speed Up (S) \\
\hline 2 & 1,163986 & 1,78 \\
\hline 3 & 1,075855 & 1,92 \\
\hline 4 & 1,098166 & 1,88 \\
\hline 5 & 1,139087 & 1,81 \\
\hline 6 & 1,162756 & 1,78 \\
\hline 7 & 1,224581 & 1,69 \\
\hline
\end{tabular}

Nilai efisiensi yang dihasilkan pada topologi jaringan paralel dengan nilai tertinggi adalah 0.89 pada saat penggunaan 2 komputer/CPU. Sedangkan untuk selanjutnya pada pengujian menggunakan $3,4,5$,6 dan 7 komputer/CPU secara berurutan mengalami penurunan nilai efisiensi.

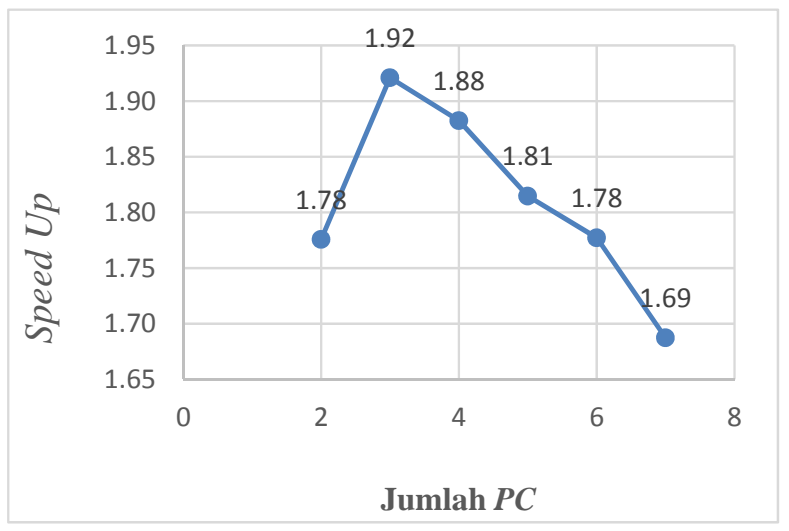

Gambar 11: Grafik Pengujian Speed Up 


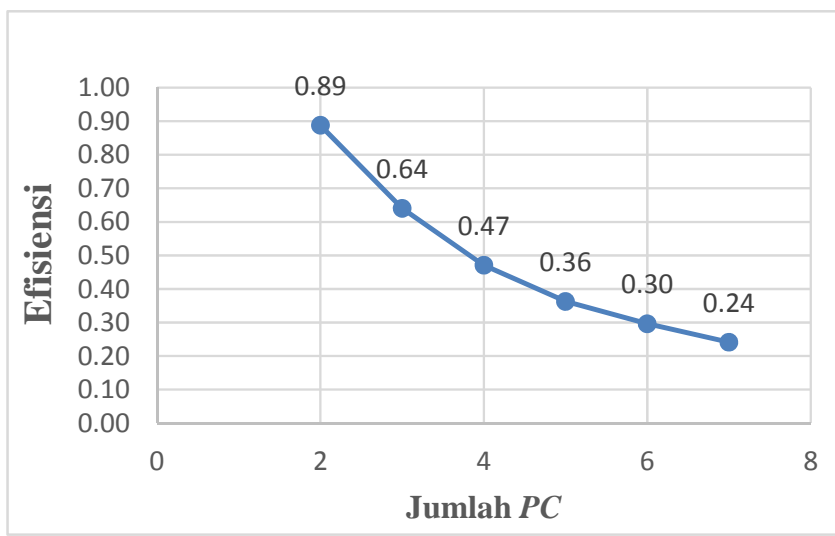

Gambar 12: Grafik Pengujian Efisensi

Pada Gambar 12 terlihat penurunan nilai efisiensi pada pengujian menggunakan 3 komputer/CPU yaitu dengan nilai efisiesi 0,64. Pengujian menggunakan 4 komputer/CPU dengan nilai efisiensi 0,47. Pengujian dengan menggunakan 5 komputer/CPU dengan nilai efiseinsi 0,36. Pengujian dengan menggunakan 6 komputer/CPU dengan nilai efiseinsi 0,30 dan Pengujian dengan menggunakan 7 komputer/CPU dengan nilai efiseinsi terendah yaitu 0,24 . Penurunan nilai efisiensi yang terjadi pada setiap peningkatan jumlah komputer/CPU disebabkan oleh terdapat komputer/CPU yang tidak bekerja (idle). Proses komunikasi yang kompleks menyebabkan terjadinya kondisi dimana komputer/CPU tidak bekerja dan menunggu untuk mendapat perintah. Hasil nilai efisiensi menunjukkan semakin banyak penggunaan komputer/CPU maka semakin menurun nilai efisiensi.

\section{KESIMPULAN}

Perancangan komputasi paralel pada penelitian ini telah berhasil berjalan sesuai dengan tahapan-tahapan yang telah direncanakan. Hasil yang didapat pada tahap pengujian menunjukan pengolahan data pasien menunjukan bahwa waktu pengolahan data pasien menggunakan program paralel MPI lebih cepat dibandingkan pengolahan data menggunakan topologi jaringan sekuensial/1 komputer/CPU. Pengujian speed up menunjukan adanya peningkatan kecepatan sampai pada penggunaan komputasi paralel pada 3 komputer/CPU. Sedangkan pada pengujian efisiensi nilai efisiensi tertinggi terdapat pada penggunaan 2 dan 3 komputer/CPU. Hal ini menunjukan bahwa untuk mengolah data sebanyak 40.036 records menggunakan program paralel MPI jumlah ideal komputer/CPU yang digunakan agar mendapatkan kecepatan maksimal adalah sebanyak 2 sampai 3 komputer/CPU. Hal tersebut menunjukan bahwa komputasi paralel menggunakan model Message Passing tidak serta merta dapat diimplementasikan pada semua jenis data dan struktur database. Jenis data dan strusktur database pada SIM RS dalam penelitian ini menunjukan bahwa semakin banyak komputer/CPU yang ikut melakukan eksekusi data dan melewati titik idealnya (2 sampai 3 komputer/CPU) mengakibatkan waktu tunggu dalam malakukan proses komunikasi semakin panjang, sehingga mempengaruhi panjang waktu eksekusi data secara keseluruhan.

\section{REFERENSI}

[1] Arta, Y. 2013. Analisa Kinerja Paralel Computing Dengan Menggunakan Perhitungan Hukum Amdahl Berbasiskan Linux.

[2] Dumbill, E. 2012. Big Data Now Current Perspective. O'Reilly Media.

[3] Dzacko, H. 2007. Basis Data (Data Base). Mangosoft.

[4] Grama A, Gupta A, Karypis G, Kumar V. 2003. Introduction to ParalelComputing. Pearson Education Limited: England.

[5] Hua S, Zhang Y. 2013. Comparison and Analysis of Paralel Computing Performance Using OpenMP and MPI. The Open Automation and Control Systems Journal.

[6] Kurniawan, A. 2010. Pemrograman Paralel dengan MPI \& C. ANDI Yogyakarta

[7] Laudon, K.C., Jane P. Laudon. 2006. Management Information Systems. $9^{\text {th }}$ edition. New Jersey: Prentice- Hall, Inc.

[8] Nashar AIE. 2011. Paralel Performance Of MPI Sorting Algorithms On Dual-Core Processor Windows-Based Systems. International Journal of Distributed and Paralel Systems (IJDPS) Vol.2, No.3.

[9] Nasir AFA, Rahman MNA, Mamat AR. 2012. A Study of Image Processing in Agriculture Application under High Performance Computing Environment. International Journal of Computer Science and Telecommunications.

[10] Olmedo E, Calleja Jdl, Benitez A, Medina MA, 2012. Point to point processing of digital images using paralel computing

[11] Petryniak R. 2008. Analysis Of Efficiency Of Paralel Computing In Image Processing Task. Cracow University of Technology.

[12] Prajapati HB, Vij SK. 2011. Analytical Study of Paralel and Distributed Image Processing. International Conference on Image Information Processing (ICIIP).

[13] Quinn MJ. 2004. Paralel Programming in C with MPI and OpenMP. McGraw-Hill Education: Singapore.

[14] Qureshi K, 2012. Perbandingan Praktis Kinerja Algoritme Sorting Paralel pada Jaringan Komputer Homogen.

[15] R. Kelly Rainer, C. 2011. Introduction to Information Systems. John Wiley \& Sons (Asia) Pte Ltd.

[16] Suprapto, 2008. Bahasa Pemrograman. Direktorat Pembinaan Sekolah Menengah Kejuruan Direktorat Jenderal Manajemen Pendidikan Dasar dan Menengah Departemen Pendidikan Nasional.

[17] Syukur A. 2013. Paralel Processing Untuk Meningkatkan Kinerja Server E-Learning Dengan Menggunakan Message Passing Interface (MPI) Studi Kasus Sma Negeri 1 Pekanbaru. Jurnal Teknologi Informasi \& Pendidikan Vol. 6.

[18] Zarkasi M, Wibisono W, Arunanto FX, 2013. Implementasi Komputasi Paralel Untuk Enkripsi Citra Berbasis AES Menggunakan JPPF. 